\title{
TWO SPEARS ON THE STAG RHYTON IN THE SCHIMMEL COLLECTION
}

\author{
Piotr TARACHA
}

This silver vessel in the shape of a stag, with a cult scene in relief around its neck, has been published by O.W. Muscarella in $1974^{1}$ and discussed ever since in almost every new publication on Hittite art and religion as in iconograhphic source of outstanding importance ${ }^{2}$. According to the dealer it was found with a silver bull rhyton and a gold statuette of the mother goddess with a child. There are good reasons to believe that these objects were used in the cult. H.G. Güterbock has ingeniously compared them with the main triad of Hittite pantheon, i.e. the Storm-god, the Sun-goddess and the Tutelary god. In this context the stag vessel dealth here with is admittedly connected with the last mentioned god ${ }^{3}$.

1. O.W. Muscarella, Ancient Art: The Norbert Schimmel Collection (Mainz 1974), No 123.

2. Cf. e.g. K. Bittel, Beitrag zur Kenntris hethitischer Bildkunst (Sitzungsher. Heidelberg, Phil.-Hist. Kl. 4) (Heidelberg 1976), 8-19 Figs. 1, 3-5; H.G. Güterbock, The Hittite Seals in the Walters Art Gallery, The Journal of the Walters Art Gallery 36 (1977), 9; S. Alp, Beiträge zur Erforschung des hethitischen Tempels (Ankara 1983), 93-100 Figs. 6a-h; A.M. Dinçol, Hethitische Hieroglyphensiegel in den Museen zu Adana, Hatay and Istanbul, Anadolu Arassturmalar1 9 (1983), 221-222 with fn. 3; R.M. Bochmer, Die Reliefkeramik von Boğazköy (BoHa XIII) (Berlin 1983), 57, 59 Fig. 49; H.G. Güterbock, A Note on the Frieze of the Stag Rhyton in the Schimmel Collection, Anadolu 22 (1981/1983) [1989], 1-5; M.N. van Loon, Anatolia in the Second Millennium B.C. (Leiden 1985), 32 Pl. XLa-b; S. Alp, Einige weitere Bemerkungen zum Hirschrhyton der Norbert Schimmel-Sammlung, in F. Imparati ed., Studi di storia e di filologia anatolica dedicati a G. Pugliese Carratelli (Florence 1988), 17-23 Figs. 1-2; E. von der Osten-Sacken, Der kleinasiatische Gott der Wildflur, IstMitt 38 (1988), 66-67 Fig. 1, Pl. 9.1.; H. G.Güterbock, Hittite kursa "Hunting Bag", in A. Leonard, Jr. and B.B. Williams, eds., Essays in Ancient Civilization Presented to H.J. Kantor (Chicago 1989), 113-119 Pls. 16-19; R. Mayer-Opificius, Hethitische Kunstdenkmäler des 13. Jahrhunderts v. Chr. in K. Emre et al., eds., Anatolia and the Ancient Near East. Studies in Honor of T. O'zgüç (Ankara 1989), 359-360 Pl. 66.1-2; V.Haas, Geschichte der hethitischen Religion (Leiden 1994), 525-526 Fig. 100a-b.

3. H.G. Güterbock, in R.M. Boehmer and H.H. Hauptmann, eds., Beiträge zur Altertumskunde Kleinasiens: Festschrift für Kurt Bittel (Mainz 1983), 217. Cf. also van Loon (n. 2), 32; von der Osten-Sacken (n.2), 67. 
Provenance of these objects is unknown. Some scholars pointed out similarities between the scene on the neck of the stag rhyton (Fig. 1) and that in the unfinished part of one of the reliefs from Alaca Höyük; both show a stag lying under the tree and a similar act of worship with a man pouring a libation. ${ }^{4}$. But this is no proof that the Schimmel thyton comes from that centre. As to its date, the vessel seems to belong to the fourteenth or thirteenth century $\mathrm{BC}^{\mathrm{s}}$.

Opinions also vary on the point how the figures of the frieze should be arranged. In some illustrations we see the whole group, including two upright spears, a stag lying under the tree, a quiver and a "hunting bag", on the very night side ${ }^{6}$, or the spears are shown separately flarking the whole scene ${ }^{7}$ Güterbock was the first who arranged the frieze properly. According to his interpretation of the scene, the spears and the tree are to be placed behind both deities on the left ${ }^{8}$. This is supported by comparing the scene with the well-known Hittite stamp seals in the British Museum, BM 115655, Dresden, Albertinum, ZV 1769, and Adana which have the elements in common with the rhyton: a seated deity, wearing a long robe and a horned pointed hat, whose attributes are a cup and a bird, worshippers in front of the deity, and behind her a stag (or a stag's head) lying under the tree, two upright spears, a bag and a quiver'. Unique to the rhyton is the young god standing on a stag, who precedes the seated deity.

The attitude and the attributes of the young god, i.e. a stag, on which he stands, a falcon and an upright lituus, are a clue to his identity. He is doubtless the tutelary god of the open country, the protector of wildlife, ${ }^{D}$ LAMMA.Líl, as described in the cult inventory text KUB 38.1 ii $1-6^{10}$.

4. Von der Osten-Sacken (n.2), 70, 71 Fig. 3; Mayer-Opificius (n. 2), $360 \mathrm{Pl}$. 66.3; Güterbock, Hittite kursa (n.2), 119 Pl. 19.

5. Cf. Bittel (n.2), 19 ("um oder bald nach 1400"); Dincol (n.2), 222 fn. 3 ("die Anfangsphase des Großreiches"); Boehmer (n. 2), 57 ("um 1400 oder in die erste Hälfte des 14. Jh."); van Loon (n.2), 32 ("around 1400 B.C."); A. Archi, Société des hommes et société des animaux, in F. Imparati, ed., Studi di storia e di filologia anatolica dedicati a G. Pugliese Carratelli (Florence 1988), 31; Mayer-Opificius (n.2), 360 (Hatušli III and Puduhepa). For a different opinion, see Alp, Beiträge (n.2), 100; idem, Einige weitere Bemerkungen (n.2) 2 l-23 (Old Hittite).

6. Muscarella (n.1) No.123; Alp, Beiträge (n.2), Figs. 6g-h; von der Osten-Sacken (n.2), Fig. 1. Cf. also van Loon (n.2), 32: "Spears, quiver and water bag were put aside after a successful hunt, in which a stag was killed."

7. Boehmer (n.2), Fig. 49; Mayer-Opificius (n.2), Pl. 66.2.

8. Güterbock, The Hittite Seals (n.2), fn. 5; idem, A Note on the Frieze (n.2), 5 Fig. 1a-b; idem, Hittite kursa (n.2), Pl. 16b. Cf. also Alp, Einige weitere Bemerkungen (n.2), 19-21 Figs 1-2.

9. Cf. Güterbock, Hittite kursa (n.2), 113-114, with ref.

10. C.G.von Brandenstein, Hethitische Götter nach Bildbeschreibungen in Keilschriftexten, MVAeG 46/2 (1943), 14-15 (Text 2). Cf. Bittel (n.2), 14-15; Alp, Beiträge (n.2), 95; Güterbock, Hittite kursa (n.2), 114 
Two hieroglyphic signs denoting the god's name on a gold label fixed to the surface of the vessel above the divine figure corroborate this identification. F. Steinherr recognized here the 'antler' sign which is well known as the logogram for the tutelary god ${ }^{11}$.

The seated deity is much harder to interpret. Some scholars considered her a goddess ${ }^{12}$, but I rather think they may be mistaken. K. Bittel pointed out a similarity between this figure and a seated male deity shown on a number of seals; in two of them, at least, the logogram of the storm god resolves all doubt ${ }^{13}$. Of course, this is no proof that the seated god depicted in the frieze on the Schimmel rhyton is the storm god, too. Who is this god, then? A label belonging to him, bearing four hieroglyphic signs, of which only two are legible, does not help us answer this question. S. Alp cited Steinherr's reading of the god's name: á-s-tá-bi (L 19-415-29-66, M 17-210-65-49), i.e. the Hurrian god Astabi, and interpreted the seated god and the young god standing on a stag as two aspects of the same tutelary god, on the assumption that the endings of the names of both the gods were written with the same hieroglyphic sign, for which Steinherr proposed the reading BI (L 66, M 49) ${ }^{14}$. The readings of the hieroglyphs in Alp did not meet with acceptance ${ }^{15}$, but most scholars are agreed that both divine figures depicted on the rhyton

11. Cf. Muscarella (n. 1), No.123; Güterbock, Hittite kursa (n.2), 115. Alp, Beiträge (n.2), 96 suggested for the second sign the phonetic value BI (Laroche (L) 66, Meriggi (M) 49), but this is not certain (see below). There is no proof either that this god was identical with Inar, cf. Archi (n.5), 31.

12. Muscarella (n.1) No.123; van Loon (n.2), 32 ("the young hunting god's mother"). Cf. also Güterbock, Hittite kursa (n.2), 115: "The Hittites had many tutelary deities, among them both gods and goddesses; so the possibility exists that our seated figure is a goddess. But this is not certain."

13. D.G. Hogarth, Hittite Seals (Oxford 1920), Pl. VII No. 1966, e. Cf. Bittel (n.2), 15-16, with fn. 24; Mayer-Opificius (n.2), 359.

14. Alp, Beiüäge (n.2), 95-96; cf. idem, Einige Bemerkungen (n.2), 18. Haas (n.2), 525 put forward a similar suggestion, although he does not accept the readings of Steinherr (cf. n. 15): "Im Mittelpunki steht der mit dem Hirsch verbundene Schutzgott der Natur, der wahrscheinlich viermal abgebildet ist: Liegend, als unter dem Baum ruhender Hirsch; in Gestalt seiner Kultobjekte, nämlich Köcher, Jagdtasche und Lanzen; sitzend auf einem Schemel mit Hirschfüßen und schließlich in der gewöhnlichen Ikonographie auf dem Hirsch stehend." Cf. also Archi (n.5), 31. Haas's interpretation of the scene raises doubts, however. The deities shown on the Schimmel rhyton belong to two distinct categories in Hittite iconography, perhaps denoting different generations of gods (this suggestion I owe to $M$. Popko). Thus, they might represent deities with a similar character and functions, but there is no proof that the same deity was contemporaneously depicted in the two aspects, viz. the seated mature god and the standing youthful god.

15. Cf. Güterbock, Hittite kursa (n.2), 115 with fn. 9; Mayer-Opificius (n.2), 359; Haas (n.2), 526. In the reliefs from Yazllikaya (Nos. 32 and 33) and numerous cuneiform texts from Boğazkale Astabi is indeed accompanied by the tutelary god Nubadig, DLAMMA and DLAMMA of Hatti: cf. KBo 11.5 i 16'-17'; 
are tutelary deities and must have had a similar character and functions ${ }^{16}$. Worthy of notice here is also the text 245/v; it describes a cult ceremony, in the course of which spears are stuck down behind a tutelary deity 'LAMMA and (branches? of) an eya-tree spread underneath: rev. 8' $n u$

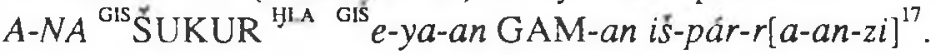

What was stated above about both the gods has much bearing on the subject of this paper which aims at interpreting two spears shown behind the seated god. In this connection the spears are most likely symbols of the hunt. Yet, in view of the fact that they always occur in pairs, both on the Schimmel rhyton and on the seals in the British Museum and Dresden, there is one question which consequently arises: Is this merely an iconographic convention in these cult scenes, or a pair of spears does reflect a practice of the hunt in the Hittite period?

Apart from Seti I's relief in the Amun temple at Karnak from the thirteenth century $\mathrm{BC}$, which depicts a Canaanite Shoshu tribesman grasping two spears of moderate length in his right hand, no counterparts are known to the present author in the iconography from the ancient Near East till the beginning of the twelfth century BC when Philistine warriors armed with a round shield, two spears, and a straight sword would appear in Egyptian reliefs of Ramesses III at Medinet $\mathrm{Habu}^{18}$. On this basis most scholars presumed that the method of fighting with two spears had its

14.142 i 9; 20.119 i 7; 35.127 2'-3'; 35.140 right col. 12'-13'; KUB 10.92 v $11-12 ; 27.1$ i $61-62 ; 27.13$ i 6 with dupl. KBo 7.279 ; 32.52 rev. 6-7; $32.896-7$; 45.3 i 42.43; Bo 796813 (H. Otten, Die Götter Nupatik Pirinkir, Heśue und Hatni-Piśaisaphi in den hethitischen Felsreliefs von Yazılıkaya, Anatolia 4 (1959), 28, 35); however, in Hurrian myths he is admittedly a war god. This is the first obstacle to Alp's identification of the seated god on the rhyton, whom I would rather consider a tutelary god, with Aśtabi. Moreover, if one accepts Alp's suggestion, in which also Güterbock concurred with him, that the bag depicted in the frieze behind the god is the object called kursa in Hittite, it appears unlikely that this is a Hurrian deity seeing that in light of the texts, the kurşa belongs to genuine Hittite tradition.

16. Cf. von der Osten-Sacken (n.2), 67; Güterbock, Hittite kursa (n.2), 115; Mayer-Opificius (n.2), 359: "zwei verschiedene, jedoch miteinander verwandte Götter."

17. H. Ertem, Boğazköy Metinlerine göre Hititler devri Anadolu'sunun Florasi (Ankara 1974), 116; V. Haas, Bemerkungen zu eja(n), AoF (1977), 270 with fn. 7; Alp, Beiträge (n.2), 98; J. Puhvel, Hittite Ethymological Dictionary, vol. 2 (Berlin and New York 1984), 254, who refers to Haas's wrong translation of the context: "fell an eya-tree for spears". Through the courtesy of $\mathrm{H}$. Otten I was able to study a photograph of this unpublished text in Mainz. Cf. also $177 / \mathrm{r} 4{ }^{\text {GIS }} e$-ya-na-an iš-pár-r[a-, Ertem, loc. cit.; Alp, op. cit., 362-363. For the discussion, see now HW2 IIE, 23-24 s.v. eya-.

18. Cf. The Battle Reliefs of King Seti I. The Epigraphic Survey (Chicago 1986), pl.3; Y. Yadin, The Art of Warfare in the Biblical Lands (London 1963), 233, 250-251, 336-337. 
origin in the Aegean and was introduced into Syria and Palestine by the Sea Peoples' armies ${ }^{19}$. The fact of the matter is that two spears ( $\delta$ vo Soupe ) were in common use in the first millenium BC Greece, bot in the hunt and the battle. Also Homer mentions them many times. The spearheads usually differ in size. The smaller one belonged to the spear which was used also for hurling, rather like a long javelin, whereas the second spear served as a thrusting weapon in hand-to-hand fighting. On the march and infantryman very often carried them in one hand ${ }^{20}$.

Additional evidence comes from the second millennium BC. The set of two spears is attested in the Aegean iconography as early as the mid fifteenth century BC on the well-known fresco of the "Captain of the Blacks" in the palace at Knossos". The wall paintings from the Mycenaean palace at Tiryns, which are dated to the fourteenth and thirteenth century BC, testify that at the time two spears were wielded first of all by hunters ${ }^{22}$. Later on, however, they were more frequently used in fighting. Mycenaean warriors, as depicted on the Late Hclladic IIIC vases from Tiryns and Lefkandi, have much in common with the Philistines of the contemporary Egyptian reliefs. Not only the infantry but also the chariot crews were occassionally armed with two spears, on account of the fact that the chariot units in the late Mycenaean period were in reality the chariot-bome infantry, similarly to the Philistine chariots and by contrast with the Egyptian ones which were equipped with the bow ${ }^{23}$.

19. Two spears were still used in Assyrian times. Cf. the reliefs in the palace of the king Sargon in Dur-Sharrukin (Khorsabad) which show foreign (Syrian?) warriors wielding two spears in scenes of fight (Room 5, slabs 3-4) and in a procession bringing tributes to the king of Assyria (Room 10, SW wall, slab 10); P. Albenda, The Palace of Sargon, King of Ássyria (Paris 1986), 85 Pls. 31 (lower) 94 and 95.

20. Cf. W. Reichel, Homerische Waffen ${ }^{2}$ (Wien 1901), 31; H. Lorimer, Homer and the Monuments (London 1950), 257 ff.; S. Foltiny, AJA 65, 1961, 288 f.; A Snodgrass, Early Greek Armour and Weapons (Edinburgh 1964), 136-139; P. Courbin, in J.P. Vernant, ed., Problèmes de la guerre en Grèce ancienne (Paris 1968), 72; J.G.P. Best, Thracian Peltasts and their Influence on Greek Warfare (Groningen 1969), 5: O. Höckmann, Lanze und Speer im spätminoischen und mykenischen Griechenland, Jahrbuch des Romisch-Germanischen Zentralmuseums Mainz 27 (1980) [1982], 112 ff.

21. P. Cassola Guida, Le armi difensive dei Micenei nelle figurazioni (Rome 1973), 121-122 (N.11), with ref.: O. Höckmann, Lanze und Speer, in H.G. Buchholz, ed., Archaeologia Homerica, Vol. I, Chap. E, Part II (Göttingen 1980), E. 288, Fig 73.

22. Cassola Guida (n.21), 124 (No. 17), 126 (No.22b), with ref.; Höckmann, (n.21), E. 288-290 Fig. 74a-b.

23. V. Karageorghis and E. Vermeule, Mycenaean Pictorial Vase Painting (Cambridge, Mass. and London 1982), 221 (XI. 18 and 28), 223 (XI. 61), with ref.; Höckmann (n.21), E. 288, 290 Fig. 75. 
Functional sets of two spears are also to be found among the funeral gifts in a number of Mycenaean "warrior graves" ${ }^{\text {"24 }}$. Suffice it to mention here the burial assemblages from Mycenae ${ }^{25}$, Tragana ${ }^{26}$, Athens ${ }^{27}$ Volos (Ancient Iolkos) $^{28}$, Mazaraki Zitsas ${ }^{29}$, Diakata, Kephallenia ${ }^{30}$, Asclepieum, $\mathrm{Cos}^{31}$, and Kato Lakkos Archanes, Crete ${ }^{32}$. In some of these spearheads occurring in twos in the graves we can observe formal differences between the blades which show that the function they had in the combat was not the same (see also above). One spearhead from Mazaraki Zitsas is distinguished by a midrib and a incised ornament whereas the second spearhead's blade is flat. One of the two spearheads found in the tholos tomb at Tragana is decorated with a very similar motif. Yet this is the only difference between both spearheads from this tomb which are identical in shape and size and were most likely cast in one mould. They can be dated to the beginning of the fourteenth century $\mathrm{BC}$, thus being the earliest of all the spearheads mentioned above. Conceming two spearheads of Höckmann's type D from Chamber Tomb 47 in the Panagia cemetery at Mycenae, Avila has pointed out that the centre of

24. Höckmann (n.20), 112 ff. Cf. also P.Taracha, History of Warfare in the Aegean Bronze Age (in preparation).

25. Chamber tombs 47 and $77 \mathrm{~A}$. Xenaki-Sakellariou, Hoi thalamotoi tafoi ton Mykenon. Anaskafes Ch. Tsounta (1887-1898) (Paris 1985), 121, 124 (X入 2480-2482) Pls. 33 and IX; 213 (X 2937. 1-4) Pls. 98 and IX; Höckmann (n.20), 134 (D 4 and 16), 142 (G 11-13), 146 (H 30); R.A.J. Avila, Bronzene Lanzen-und Pfeilspitzen der griechischen Spätbronzezeit (Prähistorische Bronzefunde V.1) (Munich 1983), 34 (No. 70), 38-39 (Nos. 83-95), 55 (Nos. 118 and 119 )

26. Höckmann (n.20), 136 (D 38 and 39); Avila (n. 25), 22-23 (Nos. 44 and 45).

27. M.A. Pantelidou, Hai proistorikai Athenai (Athens 1975), 97-106 (Grave 16),

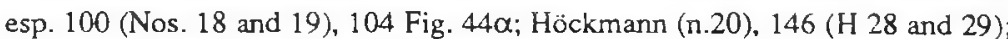
Avila (n.25), 34 (Nos. 73 and 74).

28. D.P. Theocharis, M. Theochari, Ek tou nekrotafeiou tes Iolkou, Archaiologika Aralekta ex Athenon 3 (1970), 201 Fig. 8, 202; Höckmann (n.20), 136 (D 43); Avila (n.25), 15 (No. 28); V. Adrymi-Sismani. in Ho Mykenaikos Kosmos. Pente aiones proimou ellenikou politismou 1600-1100 p.Ch. (Athens 1988), No. 231. Only one of the spearheads was illustrated.

29. I.P. Vokotopoulou, Neoi kibotioschemoi tafoi tes YE B-G periodou ex Epeirou, Archaiologike Efemeris (1969), 191 ff. Figs. 4-6 Pl. 27; Höckmann (n.20), 136 (D 41), 138 (E 3); Avila (n.25), 69-71 (Nos. 143 and 144); Th. J. Papadopoulos, in H.G. Buchholz, Ägäische Bronzezeit (Darmstadt 1987), 375 Fig. $97 \mathrm{i}-\mathrm{j}$.

30. N. Kyparisses, Kefalleniaka, Archaiologikon Deltion 5 (1919), 120 Fig. 36; Snodgrass (n.20), 120 (Type C); Avila (n.25), 63 (Nos. 134 and 135).

31. L.Morricone, Coo-Scavi e scoperte nel "Seraglio" e in localita minori (1935-1943), Annuario della Scuola archeologica di Atene 50-51 (1972-1973), 253, 256-261 Fig. 204-209; Höckmann (n. 20), 139 (F 15), 140 (F 21).

32. J. Sakellarakis, Praktika tes en Athenais Archaiologikes Hetaireias (1978), 322 Fig. 3; E. Sapouna-Sakellaraki, Archanes à l'époque mycénienne, Bulletin de correspondence hellénique 114/1 (1990), 75. 
garvity in the broader one is placed in the lower part of its blade. As the result, it was much more effective as a thrusting weapon in hand-to-hand fighting than the second spear with a slender, lanceolate blade.

Turning now to the spears depicted on the Schimmel rhyton. In spite of all uncertainty resulting from inaccuracy of the schematic pictures it is discerinble on the photographs that the spearheads also differ a little in size. And this may be plausibly explained by comparing them with Aegean counterparts. All in all, it can be suggested that the similar sets of two light spears were synchronously used in the hunt - if not also in the combat - both in Asia Minor and the Aegean as early as the mid second millennium BC. There is no denying the fact that the method of fighting with two spears was afterwards introduced and popularized by the Sea Peoples. But the set of two spears is first attested in Asia Minor more than one hundred years before then.

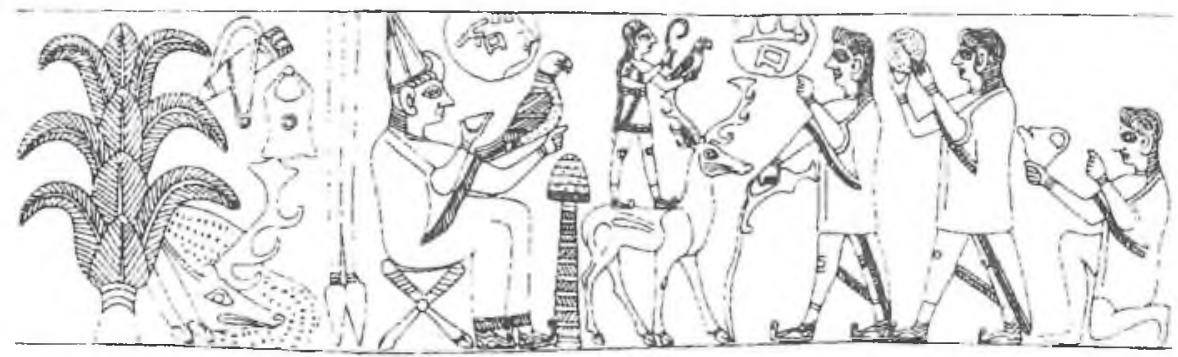

Fig. 1. Frieze on Stag Rhyton in the Schimmel Collection. 